\title{
Enhancing the Yield of Kharif Groundnut (Arachis hypogaea L.) and Quality in Entisol through Different Levels of Potassium
}

\author{
Utkarsha Amolic*, D.S. Patil and R.B. Pawar \\ Department of Soil Science and Agricultural Chemistry, College of Agriculture (Mahatma \\ Phule Krishi Vidyapeeth), Kolhapur-416004 (M.S.), India \\ *Corresponding author
}

\section{Keywords}

Potassium, Levels, time of application, Yield, Oil yield

Article Info

Accepted:

10 August 2018

Available Online:

10 September 2018

\section{A B S T R A C T}

A experiment was conducted at Post Graduate Research Farm, College of Agriculture, Kolhapur during kharif season of 2017 to study the effect of levels and time of potassium application on yield, quality of kharif groundnut (Arachis hypogaea L.) in Entisol. The experiment was laid out in Factorial Randomized Block Design with two replications comprising of four levels $\left(0,20,30,40 \mathrm{~kg} \mathrm{~K}_{2} \mathrm{O} \mathrm{ha}^{-1}\right)$ and five time of application (Sowing, flowering, pegging) of potassium. The results revealed that successive increase in levels of potassium showed significant effect on yield and yield attributes of groundnut crop, along with quality. Significantly highest dry pod, kernel and haulm of groundnut were increased significantly with increasing levels of potassium and highest yield $(30.08,21.20,36.51 \mathrm{q}$ $\mathrm{ha}^{-1}$, respectively) was recorded by application of $40 \mathrm{~kg} \mathrm{ha}^{-1} \mathrm{~K}_{2} \mathrm{O}$. The oil content and oil yield of groundnut was significantly highest $(49.40 \%)$ and $\left(1047.33 \mathrm{~kg} \mathrm{ha}^{-1}\right)$ with application of $40 \mathrm{~kg} \mathrm{~K}_{2} \mathrm{O} \mathrm{ha}{ }^{-1}$. Effect of time of potassium application and interactions in respect of yield of dry pod, kernel, haulm, oil content, oil yield of groundnut were found non-significant. The shelling percentage ranged $67-70 \%$ but the effect of various treatments on shelling percentage was non-significant.

\section{Introduction}

Oilseed constitutes the principal commercial crops of India and occupies an important place in Indian economy, as it directly involves in food and industrial needs. Among the oilseed crops grown in India, groundnut crop plays a predominant role in oilseed production. Groundnut is a heavy feeder of potassium and an adequate supply of this nutrient is indispensable to harvest a good crop of groundnut. As regards the nutritional value of groundnut its seed contains about 40-50 per cent oil, 20-30 per cent protein and 10-20 per cent carbohydrates (Okello et al., 2010).

Potassium is one of the 3 main pillers of balanced fertilizer use, along with nitrogen $(\mathrm{N})$ and phosphorus $(\mathrm{P})$. The major functions are enzymes involved in photosynthesis, stomatal activity (water use), transport of sugars, water and nutrient synthesis of protein, translocation of carbohydrate. Also improve the crop quality, kernel size of groundnut, test weight and shelling percentage (Bhosle et al., 2011; Rathore et al., 2014). Out of large 
percentage of area in India, very little or no potassium $(\mathrm{K})$ fertilizers are being applied and therefore it mainly comes from potassium reserves of the soil. Potassium fertilizers are one commodity for which country depends solely on import. Application of required quantity of nutrients at right time by adopting proper method enhances the groundnut pod yield and quality. Since the growth of groundnut is intensive from 30 DAS to 70 DAS, appropriate time of fertilizer application in required quantity is extremely critical to match the nutrient supply with demand prevailing the critical stages of groundnut.

Most research data showed that basal and split application of potassium is equally good, but some recent studies conducted on oilseed crop showed beneficial effects of splits doses of potassium over basal doses, due to fixation and leaching loses in intensively cropped area. Therefore, keeping this in view of the effect of varying levels and time of potassium application on yield and quality of groundnut were studied in present investigation.

\section{Materials and Methods}

The field experiment was conducted during the kharif season of 2017-18 at Post Graduate Research Farm, College of Agriculture, Kolhapur $\left(16^{0} 42^{\prime}, \mathrm{N}\right.$ latitude, $74^{0} 14^{\prime} \quad \mathrm{E}$ longitude and $548 \mathrm{~m}$ AMSL) in sandy clay loam soil (52.92\% sand, $15.26 \%$ silt and $31.82 \%$ clay) containing available N (158.36 $\left.\mathrm{kg} \mathrm{ha}^{-1}\right)$, moderately high $\mathrm{P}\left(22.17 \mathrm{~kg} \mathrm{ha}^{-1}\right)$ and $\mathrm{K}\left(246.40 \mathrm{~kg} \mathrm{ha}^{-1}\right)$. The status of organic carbon content $(0.44 \%)$ was moderate and moderately calcareous with 4.5 per cent $\mathrm{CaCO}_{3}$ equivalent. The $\mathrm{pH}, \mathrm{EC}$ values were 7.6 and $0.26 \mathrm{dS} \mathrm{m}^{-1}$, respectively. The weekly mean maximum and minimum temperature during crop growth period ranged between $25^{\circ} \mathrm{C}$ to $34^{\circ} \mathrm{C}$ and $16^{\circ} \mathrm{C}$ to $23^{\circ} \mathrm{C}$, respectively. The weekly mean relative humidity during the morning and evening ranged between 86 to 92 per cent and 53 to 81 per cent, respectively. The weekly mean rainfall received during the experimental period ranged between $0.3 \mathrm{~mm}$ to $25 \mathrm{~mm}$. The weekly mean evapotranspiration $\left(\mathrm{mm} \mathrm{hr}^{-1}\right)$ ranged between $0.8 \mathrm{~mm} \mathrm{hr}^{-1}$ to $9.7 \mathrm{~mm} \mathrm{hr}^{-1}$. The experiment was laid out in the factorial randomized block design. The treatments consisted of four levels of potassium viz.0, 20, 30 and $40 \mathrm{~kg} \mathrm{ha}^{-1}$ which were supplied through five different time of potassium application viz Sowing, flowering, pegging. Groundnut was sown on 28.06 .2016 with a spacing $30 \mathrm{~cm}$ x $15 \mathrm{~cm}$. All the recommended agronomic practices were adopted. Recommended dose of $\mathrm{N}$ and $\mathrm{P}_{2} \mathrm{O}_{5}$ (25:50 $\left.\mathrm{kg} \mathrm{ha}^{-1}\right)$ was applied to all treatments through Urea and Single super phosphate and potassium through MOP as per treatments. Oil content was determined by Soxhlet Ether Extract method (A.O.A.C.2016).

\section{Results and Discussion}

\section{Effect on dry pod, kernel and haulm yield of groundnut}

The yield of dry pod, kernel and haulm of groundnut were increased significantly with increasing levels of potassium and highest yield $\left(30.08,21.20,36.51 \mathrm{q} \mathrm{ha}^{-1}\right.$, respectively) were recorded by application of $40 \mathrm{~kg} \mathrm{~K}_{2} \mathrm{O}$ $\mathrm{ha}^{-1}$. While, Interaction effects of potassium levels and time of potassium application were found non-significant in relation to dry pod, kernel, haulm yield of groundnut. Potassium play vital role in maintaining balance in enzymatic, stomatal activity (water use), transport of sugars, water and nutrients and synthesis of protein, starch and photosynthesis, carbohydrate metabolism, translocation of carbohydrate thus $\mathrm{K}$ application increased growth and yield attributes in groundnut. The results are in close conformity with the observations recorded by Rathore et al., (2014), Borah et al., (2017) and Vinod Kumar et al., (2000) 
Effect on yield attributes of groundnut

In general, the yield attributes viz., number of filled and unfilled pods and shelling percentage were influenced by different levels and sources of potassium applications. Significantly highest number of filled pods plant $^{-1}$ (40.06) were recorded by application of $40 \mathrm{~kg} \mathrm{~K} \mathrm{~K}_{2} \mathrm{O} \mathrm{ha}^{-1}$ and significantly lowest unfilled pods plant ${ }^{-1}$ were recorded with $\mathrm{L}_{4}-40$ $\mathrm{kg} \mathrm{K}_{2} \mathrm{O} \mathrm{ha}^{-1}$ (8.42). However, Effect of time of potassium application and interaction was found non-significant in relation to number of filled and unfilled pods plant ${ }^{-1}$. The results are in close agreement with the findings reported by Reddy et al., (2011) who also reported superior performance of groundnut to various levels of potassium (Table 1).

Table.1 Yield and Yield attributes of groundnut influenced by different potassic levels and time of application

\begin{tabular}{|c|c|c|c|c|c|c|}
\hline & Dry pod yield & Kernel yield & haulm yield & & Filled pods & $\begin{array}{l}\text { Unfilled } \\
\text { pods }\end{array}$ \\
\hline Treatments & $\left(q h^{-1}\right)$ & $\left(q h^{-1}\right)$ & $\left(\mathrm{q} \mathrm{ha}^{-1}\right)$ & Shelling \% & Plant $^{-1}$ & Plant $^{-1}$ \\
\hline \multicolumn{7}{|c|}{$\begin{array}{l}\text { Levels of potassium } \\
\left(\mathrm{kg} \mathrm{h}^{-1}\right)\end{array}$} \\
\hline $\mathrm{L}_{1}(0)$ & 21.22 & 14.22 & 30.41 & 67.06 & 24.27 & 9.48 \\
\hline $\mathrm{L}_{2}(20)$ & 25.05 & 17.57 & 34.82 & 68.43 & 32.08 & 9.02 \\
\hline $\mathrm{L}_{3}(30)$ & 28.75 & 19.11 & 35.52 & 69.49 & 36.56 & 8.56 \\
\hline $\mathrm{L}_{4}(40)$ & 30.08 & 21.20 & 36.51 & 69.50 & 40.06 & 8.42 \\
\hline S.E. \pm & 0.54 & 0.43 & 0.93 & 0.37 & 0.68 & 0.13 \\
\hline $\mathrm{CD}$ at $5 \%$ & 1.62 & 1.28 & 2.78 & 1.11 & 2.03 & 0.40 \\
\hline \multicolumn{7}{|c|}{$\begin{array}{l}\text { Time of potassium } \\
\text { application }\end{array}$} \\
\hline $\mathrm{T}_{1}$ & 27.19 & 18.87 & 35.57 & 69.25 & 32.85 & 9.20 \\
\hline $\mathrm{T}_{2}$ & 26.30 & 18.25 & 34.52 & 69.41 & 33.05 & 8.79 \\
\hline$T_{3}$ & 26.19 & 17.91 & 34.21 & 69.39 & 33.05 & 8.65 \\
\hline $\mathrm{T}_{4}$ & 25.92 & 17.64 & 33.72 & 68.07 & 33.20 & 8.86 \\
\hline T5 & 25.76 & 17.47 & 33.56 & 67.99 & 33.70 & 8.85 \\
\hline S.E. \pm & 0.61 & 0.48 & 1.05 & 0.42 & 0.77 & 0.15 \\
\hline $\mathrm{CD}$ at $5 \%$ & NS & NS & NS & NS & NS & NS \\
\hline \multicolumn{7}{|c|}{ Interaction ( $\mathbf{L} x \mathbf{T})$} \\
\hline S.E. \pm & 1.22 & 0.96 & 2.10 & 0.84 & 1.54 & 0.30 \\
\hline $\mathrm{CD}$ at $5 \%$ & NS & NS & NS & NS & NS & NS \\
\hline
\end{tabular}


Table.2 Effect of potassium levels and time of application on oil content and yield of groundnut

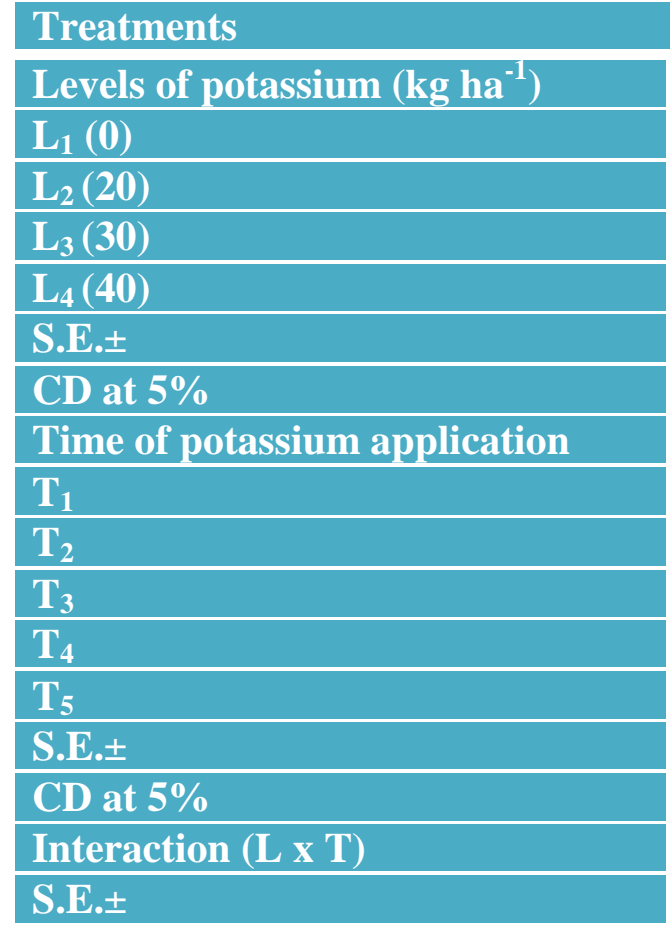

CD at 5\%

The shelling percentage was not much more influenced by the different levels and sources of potassium and it was found non-significant. The highest shelling percentage was recorded in $\mathrm{L}_{4^{-}} 40 \mathrm{~kg} \mathrm{~K}_{2} \mathrm{O}$ ha $^{-1}(69.50 \%)$. While, Effect of time of potassium application and interaction were found non-significant in relation to shelling percentage Similar findings have been reported by Borah et al., (2017) and Nadia Hemeid (2015).

\section{Effect on oil content, oil yield of groundnut}

The oil content of groundnut improve significantly with the graded doses of potassium application. Significantly highest $(49.40 \%)$ oil content of groundnut kernel was reported with application of $40 \mathrm{~kg} \mathrm{~K} \mathrm{~K}_{2} \mathrm{O} \mathrm{ha}{ }^{-1}$ but effect of time of potassium application and interactions were found non-significant (Table 2). The results indicated that, significantly highest oil yield $(1047.33 \mathrm{~kg}$ $\left.\mathrm{ha}^{-1}\right)$ was recorded by application of $\mathrm{L}_{4}(40 \mathrm{~kg}$
Oil content \%

45.98

47.10

48.65

49.40

0.23

0.69

47.22

47.44

47.88

48.03

48.33

0.26

NS

0.52

NS
Oil yield $\left(\mathrm{kg} \mathrm{ha}^{-1}\right)$

\begin{tabular}{|c|}
\hline 653.56 \\
\hline 827.32 \\
\hline 930.21 \\
\hline 1047.33 \\
\hline 22.35 \\
\hline 66.15 \\
\hline 892.71 \\
\hline 869.61 \\
\hline 861.47 \\
\hline 850.71 \\
\hline 848.54 \\
\hline 24.98 \\
\hline NS \\
\hline 49.97 \\
\hline NS
\end{tabular}

$\mathrm{K}_{2} \mathrm{O}$ ha $^{-1}$ ) which was significantly superior over rest of $\mathrm{K}_{2} \mathrm{O}$ levels. Balanced use of nutrients might have improved the yield attributing characteristics like root and plant growth, nutrient uptake, physical, chemical and biological activities which ultimately results in higher kernel and oil yield. Umar et al., (1999), Rathore et al., (2014), Gupta et al., (2011) and Borah et al., (2017) have reported similar findings in relation to oil content and oil yield of groundnut. The result from the present study revealed that, Pod, kernel and haulm yield, oil content and oil yield of groundnut was significantly increased due to the application of increasing levels of potassium i.e. $40 \mathrm{~kg} \mathrm{~K}_{2} \mathrm{O}$ ha $^{-1}$ over control and there is no significant difference observed with time of potassium application.

\section{References}

A.O.A.C. (2016) Official Methods of Analysis Association of Official 
Agricultural Chemists International $20^{\text {th }}$ Edition, 2016. Book by AOAC International, 2016. Editor. Dr. George W. Latimer, Jr.

Bhosle, N.D., Dabhi, B.M., Gaikwad, V.P. and Agarwal, M.C. (2011) Influence of potash and sulphur levels on yield, quality and economics of sesamum (Sesamum indicum L.). International Journal Plant Science 6, 335-337.

Borah, B., Patil, D.S. and Pawar, R.B. (2017) Enhancing kharif groundnut (Arachis hypogaea L.) yield and quality in entisol through potassic fertilizer management. International Journal of Current Microbiology and Applied Sciences 6, 4068-4074.

Gupta, V., Bhadauria, V.P. and Agarwal, R.L. (2011) Effect of nitrogen and split doses of potassium on quality aspect of Brassica species. African Journal of Agricultural Research 6, 285-288.

Hemeid, N.M. (2015) Effect of different sources and levels of potassium fertilization on productivity of peanut grown under sandy soil conditions. Journal of Soil Science and Agricultural Engineering 6, 1441-1454.

Musa, A.M., Singh, L., Tame V.T. and Bubarai, M.L. (2017) Nitrogen, Phosphorus and Potassium Uptake by Some Varieties of Groundnut (Arachis hypogaea L.) As Influenced By
Phosphorus Application in Yola and Mubi. IOSR Journal of Agricultural and Veterinary Science. 10, 40-45.

Okello, D.K., Biruma, M. and Deom, C.M. (2010) Overview of groundnut research in Uganda: Past, present and future. African Journal Biotechnology 9, 644859.

Rathore, S.S., Chaudhary, D.R., Vaisya, L.K., Shekhawat Kapila and Bhatt, B.P. (2014) Schoenite and Potasium Sulphate: indigenous potassic fertilizer for rainfed groundnut (Arachis hypogea L.) Indian Journal traditional Knowledge 13, 222-226.

Reddy, S.T., Reddy, D.S. and Reddy, G.P. (2011) Fertilizer management for maximizing productivity and profitability of export oriented groundnut (Arachis hypogaea L.) Journal Research Angrau. 39, 83-85.

Umar, S., Bansal, S. K., Patricia, I. and Magen, H. (1999) Effect of foliar fertilization of potassium on yield, quality, and nutrient uptake of groundnut. Journal of Plant Nutrition 22, 1785-1795.

Vinod Kumar, B.C., Ghose, Ravibhat and Karmakar, S. (2000) Effect of irrigation and fertilizer on yield, water- use efficiency and nutrient uptake of summer groundnut. Indian Journal of Agronomy 45, 756-762.

\section{How to cite this article:}

Utkarsha Amolic, D.S. Patil and Pawar, R.B. 2018. Enhancing the Yield of Kharif Groundnut (Arachis hypogaea L.) and Quality in Entisol through Different Levels of Potassium. Int.J.Curr.Microbiol.App.Sci. 7(09): 1398-1402. doi: https://doi.org/10.20546/ijcmas.2018.709.168 